\title{
The C-peptide response to a standard mixed meal in a group of Brazilian type 1 diabetic patients
}

\author{
R. Pozzan, \\ T. Dimetz, \\ H.M. Gazzola \\ and M.B. Gomes
}

\author{
Laboratório de Endocrinologia, Disciplina de Diabetes, \\ Departamento de Medicina Interna, \\ Universidade do Estado do Rio de Janeiro, \\ Rio de Janeiro, RJ, Brasil
}

\author{
Correspondence \\ R. Pozzan \\ Rua Tiradentes, 199, apto 1404 \\ 24210-510 Niterói, RJ \\ Brasil \\ Fax: 55 (021) 529-4444 \\ E-mail: pozzan@urbi.com.br \\ Research supported by CNPq \\ (No. 411560-91).
}

Received December 2, 1996

Accepted August 18, 1997

\begin{abstract}
In order to analyze the different parameters used in the interpretation of C-peptide response in a functional test, we compared a group of 26 type 1 diabetics aged $21.1 \pm 8.2$ years, with a diabetes duration of 7.9 \pm 6.7 months, with a group of 24 non-diabetic subjects aged $25.0 \pm 4.4$ years. A standard mixed meal of $317 \mathrm{kcal}$ was used as a stimulus. Blood sampling for C-peptide determinations was performed at regular intervals. Although all the studied C-peptide variables were significantly lower in the diabetic group $(\mathrm{P}<0.0001)$, some overlapping of parameters was observed between the two groups. The highest degree of overlapping was found for basal value (BV) (30.8\%) and percent increase $(42.31 \%)$, and the lowest for incremental area, absolute increase, peak value (PV) $(3.8 \%)$, and total area $(7.7 \%)\left(\chi^{2}=31.6\right.$, $\mathrm{P}<0.0001)$. We did not observe a definite pattern in the time of maximum response among the 21 diabetics who showed an increase in C-peptide levels after the stimulus. In this group, however, there was a highly significant number of late responses $(120 \mathrm{~min})\left(\chi^{2}=5.7\right.$, $\mathrm{P}<0.002)$. Although BV showed a significant correlation with PV $\left(r_{S}\right.$ $=0.95, \mathrm{P}<0.0001$ ), the basal levels of $\mathrm{C}$-peptide did not differentiate the groups with and without response to the stimulus. We conclude that the diabetic group studied showed delayed and reduced C-peptide responses, and that the functional test can be an important tool for the evaluation of residual $\beta$ cell function.
\end{abstract}

\section{Introduction}

The determination of C-peptide is a widely used method to evaluate residual insulin secretion in type 1 diabetic patients using exogenous insulin (1-5). However, comparison between the studies is impaired by the variety of methods of stimulation used and time of sampling.

C-peptide is measured both in fasting
Key words

- Type 1 diabetes mellitus

- C-peptide response

- Mixed meal test

- Beta cell function samples $(6,7)$ and after different stimuli $(3,4,8)$. Generally a good correlation between fasting and maximum values after the stimulus has been reported $(3,9,10)$. In the interpretation of the functional test, different variables have been used, such as the maximum value after the stimulus $(3,10-13)$, the area under the curve $(14,15)$, the increment after the stimulus (16), or the sum of the curve values (17), but the superiority of one of 
them has not been established up to now.

The aim of the present study was to evaluate the different parameters that can be used in the analysis of the $\mathrm{C}$-peptide response to a standardized test meal in a group of insulindependent diabetics, and to determine the importance of performing the functional test.

\section{Subjects and Methods}

We studied 26 type 1 diabetic outpatients, 12 women and 14 men, aged 10-40 years $(21.1 \pm 8.2)$, with diabetes duration of 1-24 months $(7.9 \pm 6.7)$. The patients were regularly seen at the Diabetes Unit of the Hospital da Universidade do Estado do Rio de Janeiro and were classified according to the National Diabetes Data Group criteria (18). All of them had ketonuria or ketoacidosis by the time of the onset of the disease, and had been using insulin since diagnosis.

For comparison purposes, we used 24 non-diabetic individuals (students, residents, physicians and others from the university staff) without a family history of diabetes, 14 women and 10 men aged $16-36$ years (25.0 \pm 4.4).

In patients with recent onset of the disease, the C-peptide test was only performed after the disappearance of ketonuria. A standard mixed meal consisting of $200 \mathrm{ml}$ of $2 \%$ cow milk and seven crackers was used as a stimulus (317 kcal: $55.7 \%$ carbohydrates, $14.8 \%$ proteins and $29.5 \%$ fats). After an overnight fast of $10 \mathrm{~h}$, an indwelling catheter was inserted into a forearm vein and blood samples were obtained $15 \mathrm{~min}$ before the standard meal ingestion, and then at intervals of $0,30,60$ and $120 \mathrm{~min}$. In the diabetic group, the usual dose of intermediate-acting insulin was administered immediately before the beginning of the test.

After blood coagulation, samples were centrifuged at $3000 \mathrm{rpm}$ for $15 \mathrm{~min}$ and glucose was measured immediately. Serum for C-peptide measurements was stored at $-20^{\circ} \mathrm{C}$, without protease inhibitors, for a maxi- mum period of three months.

C-peptide levels were measured by radioimmunoassay (Diagnostic Products Corporation, Los Angeles, CA) after the removal of insulin antibodies by precipitation with polyethylene glycol (PEG). The lower limit of detection for this assay is $0.05 \mathrm{ng} / \mathrm{ml}$. Intra- and interassay variations were $9.1 \%$ and $7.0 \%$, respectively. Glucose was measured by an enzymatic colorimetric automated method (Roche Diagnostic Basel, Switzerland).

The variables of the C-peptide response curve analyzed were 1) basal value (BV) (ng/ $\mathrm{ml})=$ the mean of C-peptide values at $-15 \mathrm{~min}$ and zero; 2) peak value (PV) $(\mathrm{ng} / \mathrm{ml})=$ the highest value after the standard meal stimulation. In patients who showed no increase after stimulation, $\mathrm{PV}$ was considered to be equal to $\mathrm{BV} ; 3)$ absolute increase (AI) $(\mathrm{ng} / \mathrm{ml})=$ the absolute difference between PV and BV; 4) percent increase $(\mathrm{PI})(\%)=(\mathrm{PV}-\mathrm{BV}) / \mathrm{BV} \mathrm{x}$ 100 ; 5) total area (TA) $\left(\mathrm{ng} \mathrm{min}^{-1} \mathrm{ml}^{-1}\right)=$ the area below the curve obtained by a numerical integral calculation; 6) incremental area (IA) (ng $\mathrm{min}^{-1} \mathrm{ml}^{-1}$ ) $=$ the area below the curve, and above baseline obtained by a numerical integral calculus. Before the calculation of IA, points below the baseline were replaced by the basal value; in other words, negative areas were ignored (19).

For patients whose C-peptide values after stimulation were lower than or equal to the basal ones, AI, IA, and PI were considered to be zero.

The glucose variables analyzed were basal value, peak value, absolute increase, percent increase, total area, and incremental area, obtained as described for the C-peptide variables.

We also analyzed the time of maximum C-peptide response to the stimulus. In the diabetic group the analysis of this parameter was only performed in patients who showed an increase in C-peptide levels.

Data were analyzed statistically by nonparametric methods (20) since the variables of 
the C-peptide curve did not show normal distribution. The tests used were the following: 1 ) Mann-Whitney test to compare the values of the C-peptide variables for the diabetic and non-diabetic groups, as well as BV for diabetics with and without a response after the stimulus. These results are reported as median (minimum-maximum); 2) Spearman's rank correlation $\left(r_{S}\right)$ to test the degree of correlation between BV and PV and between the glucose and C-peptide variables in the diabetic group; 3 ) chi-square test $\left(\chi^{2}\right)$ with Yates correction, for comparison of the frequency of the time of maximum response to the stimulus between the diabetic and non-diabetic groups, and the overlap in C-peptide variables between the two groups. The level of significance was set at 0.05 .

\section{Results}

Glucose and C-peptide values at the different sampling times are listed in Table 1. The correlation between glucose and C-peptide variables in the diabetic group is reported in Table 2.

Although all the C-peptide variables studied were significantly lower in the diabetic group $(\mathrm{P}<0.0001)$, overlapping of all parameters was observed between the two groups (Figures 1, 2, and 3), and was highest for PI $(42.3 \%)$ and BV (30.8\%). The lowest overlap was observed for PV, AI, IA (3.8\%) and TA $(7.7 \%)\left(\chi^{2}=31.6, \mathrm{P}<0.0001\right)$.

Despite the significant correlation found between BV and PV $\left(r_{S}=0.95, P<0.0001\right)$, $\mathrm{C}$-peptide basal values were similar in patients with $(\mathrm{N}=21)$ and without $(\mathrm{N}=5)$ a response to the stimulus $(0.6 \mathrm{ng} / \mathrm{ml}(0.1-2.2$ $\mathrm{ng} / \mathrm{ml})$ vs $0.5 \mathrm{ng} / \mathrm{ml}(0.2-2.8 \mathrm{ng} / \mathrm{ml}), \mathrm{P}>0.05)$.

The 21 diabetics who showed increased C-peptide levels after the stimulus presented the following distribution for time of maximum response: 7 patients at $30 \mathrm{~min}, 6$ at 60 $\mathrm{min}$, and 8 at $120 \mathrm{~min}$. In non-diabetics, PV was found at 30,60 and $120 \mathrm{~min}$ in 6,16 and 2 individuals, respectively $\left(\chi^{2}=8.1, \mathrm{P}<0.03\right)$
Table 1 - Glucose and C-peptide levels of the groups studied at the different sampling times.

Data are reported as means \pm SD

\begin{tabular}{lcclrr}
\hline \multirow{2}{*}{ Time of sampling } & \multicolumn{2}{c}{ C-peptide $(\mathrm{ng} / \mathrm{ml})$} & & \multicolumn{2}{c}{ Glucose $(\mathrm{mg} / \mathrm{dl})$} \\
\cline { 2 - 3 } \cline { 5 - 6 } & Diabetics & Non-diabetics & & Diabetics & Non-diabetics \\
\hline Basal & $0.8 \pm 0.7$ & $2.0 \pm 0.6$ & & $184.0 \pm 107.2$ & $80.9 \pm 7.9$ \\
$30 \mathrm{~min}$ & $0.8 \pm 0.9$ & $3.2 \pm 1.2$ & & $213.3 \pm 108.8$ & $97.3 \pm 12.4$ \\
$60 \mathrm{~min}$ & $0.9 \pm 0.7$ & $4.1 \pm 1.1$ & & $246.1 \pm 105.1$ & $101.8 \pm 12.6$ \\
$120 \mathrm{~min}$ & $0.9 \pm 0.6$ & $3.3 \pm 1.9$ & & $245.3 \pm 103.2$ & $97.7 \pm 17.5$
\end{tabular}

Table 2 - Correlation of glucose and C-peptide variables in the diabetic group $\left(r_{s}\right)$

${ }^{*} \mathrm{P}>0.05, \mathrm{r}_{\mathrm{s}}=$ Spearman coefficient of correlation. $\mathrm{BV}=$ Basal value; $\mathrm{PV}=$ peak value; $\mathrm{Al}=$ absolute increase; $\mathrm{PI}=$ percent increase; $\mathrm{TA}=$ total area; $\mathrm{IA}=$ incremental area .

\begin{tabular}{lcccccc}
\hline Glucose variables & \multicolumn{6}{c}{ C-peptide variables } \\
\cline { 2 - 7 } & BV & PV & Al & PI & TA & IA \\
\hline BV & $0.08^{*}$ & $0.07^{*}$ & $-0.06^{*}$ & $-0.16^{*}$ & $0.09^{*}$ & $0^{*}$ \\
PV & $-0.10^{*}$ & $-0.07^{*}$ & $-0.10^{*}$ & $-0.19^{*}$ & $-0.11^{*}$ & $-0.06^{*}$ \\
Al & $-0.30^{*}$ & $-0.30^{*}$ & $-0.17^{*}$ & $-0.13^{*}$ & $-0.31^{*}$ & $0.15^{*}$ \\
PI & $-0.20^{*}$ & $-0.30^{*}$ & $-0.13^{*}$ & $-0.01^{*}$ & $-0.29^{*}$ & $-0.17^{*}$ \\
TA & $-0.05^{*}$ & $-0.05^{*}$ & $0.11^{*}$ & $-0.21^{*}$ & $-0.06^{*}$ & $-0.06^{*}$ \\
IA & $-0.26^{*}$ & $-0.30^{*}$ & $-0.19^{*}$ & $-0.09^{*}$ & $-0.21^{*}$ & $-0.31^{*}$
\end{tabular}

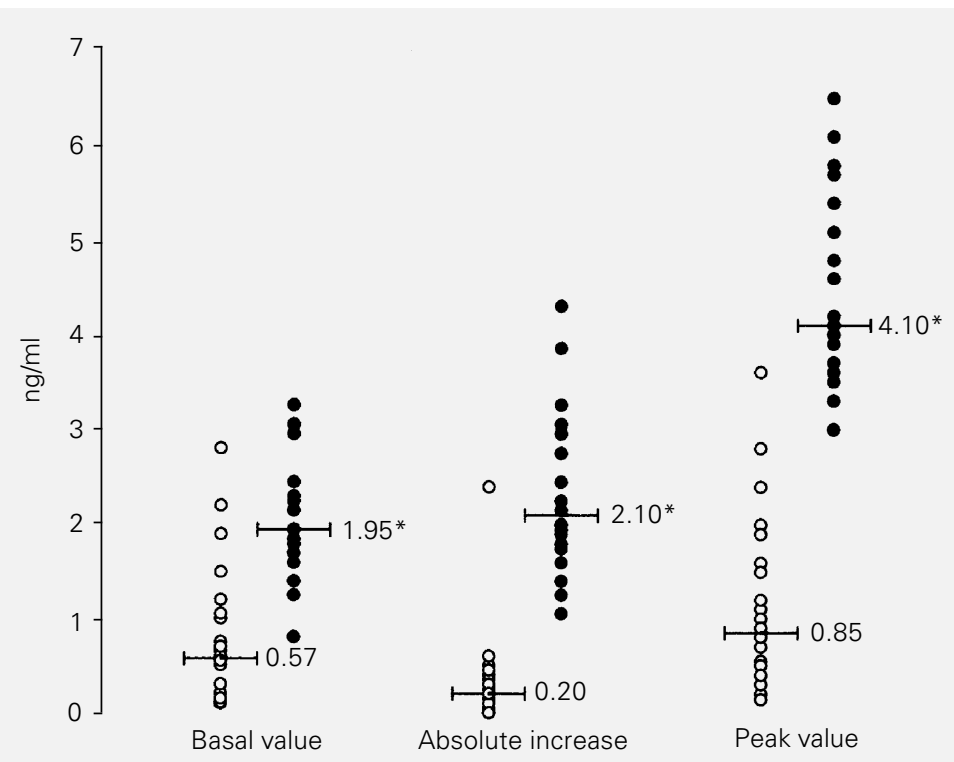

Figure 1 - Comparison between type 1 diabetics and non-diabetics for the C-peptide response to a test meal in terms of basal value, absolute increase and peak value. Open circles, Diabetics $(N=26)$; filled circles, non-diabetics $(N=24) ;{ }^{*} P<0.0001$ compared to the diabetic group (Mann-Whitney test). 
(Figure 4). A significant difference in the time of maximum response between diabetics and non-diabetics was observed at 60 and $120 \min \left(\chi^{2}=7.9, \mathrm{P}<0.005\right.$ and $\chi^{2}=5.7$, $\mathrm{P}<0.002$, respectively). No difference was observed at $30 \min \left(\chi^{2}=0, P>0.05\right)$.

\section{Discussion}

In the present study we analyzed some parameters that can be used to evaluate the
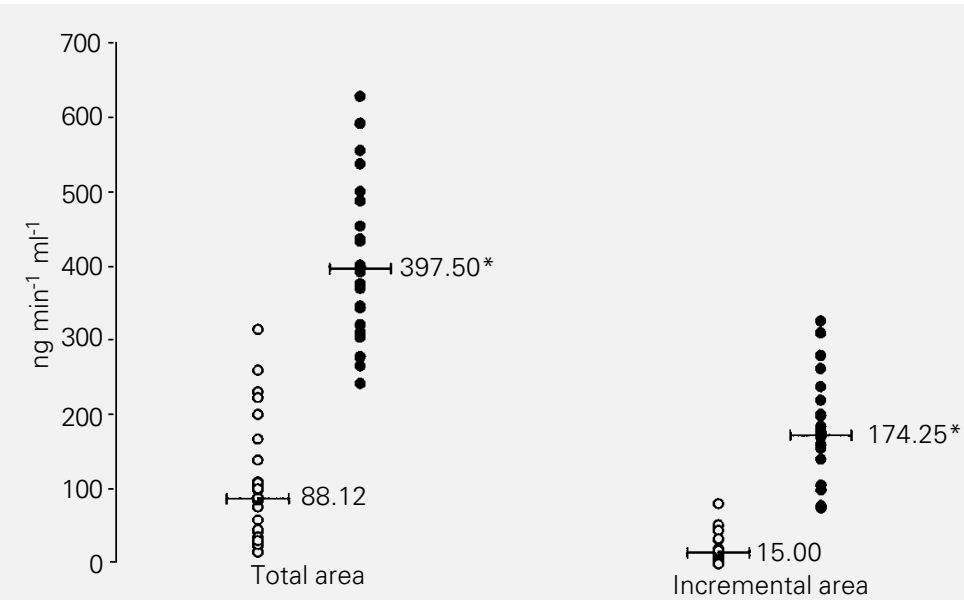

Figure 2 - Comparison between type 1 diabetics and non-diabetics for the C-peptide response to a test meal in terms of total area under the curve and incremental area. Open circles, Diabetics $(N=26)$; filled circles, non-diabetics $(N=24)$; ${ }^{*} P<0.0001$ compared to the diabetic group (Mann-Whitney test).

Figure 3 - Comparison between type 1 diabetics and non-diabetics for the C-peptide response to a test meal in terms of percent increase. Open circles, Diabetics $(\mathrm{N}=26)$; filled circles, non-diabetics $(N=24) ;{ }^{*} P<0.0001$ compared to the diabetic group (Mann-Whitney test).

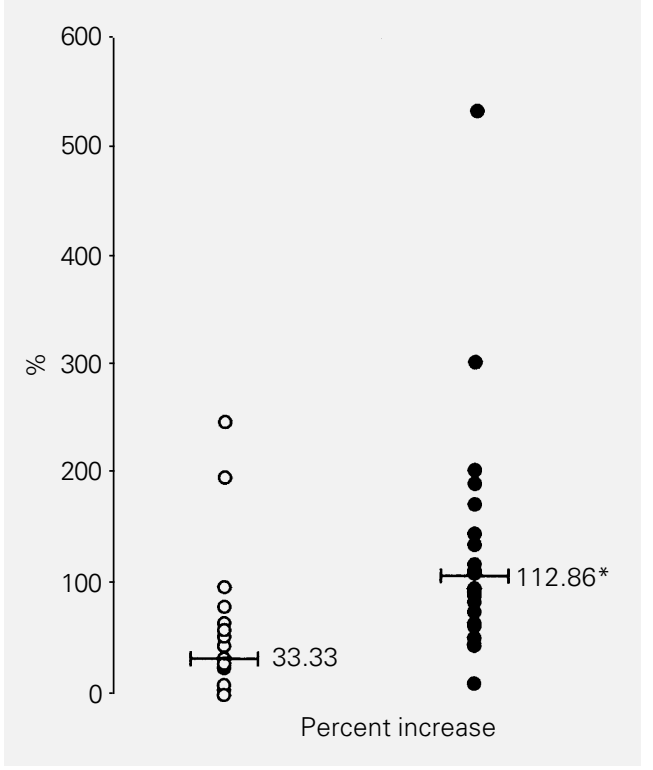

C-peptide response to a standard meal in a group of type 1 diabetic patients.

To reproduce as much as possible the usual condition of the patients, we decided to maintain their usual insulin dose before the test meal. One study (2) reported no difference in C-peptide response to Sustacal ${ }^{\circledR}$, with and without the use of exogenous insulin. In that study, as in the present report, no patient developed hypoglycemia during the test.

A possible influence of the high levels of glucose on C-peptide responses in the diabetic group was studied by correlating the glucose and C-peptide variables. No significant correlation was found, which permitted us to study C-peptide variables without adjustments for glucose levels.

As expected, the diabetic group had significantly lower levels of all the C-peptide variables than the non-diabetic group. However, some patients showed levels similar to those observed in the non-diabetic group (Figures 1, 2, and 3).

Elevated levels of C-peptide in diabetic patients have been reported $(7,8,21)$. In one study (7), $12.5 \%$ of patients had basal Cpeptide levels similar to those observed in non-diabetics, and 3\% showed values above the normal ones. Basal values remained high even when C-peptide was measured after proinsulin extraction $(7,21)$. The explanation for these elevated C-peptide levels in type 1 diabetics is not known (21). In our group of diabetics, all patients whose BV showed overlapping with the non-diabetic group could be distinguished from them by the variables determined after the stimulus. The only exception was one patient (3.8\%) whose clinical and laboratory data indicated that he was probably in the "honeymoon" or remission phase.

With the exception of PI, the other variables measured after the stimulus (PV, AI, IA, and TA) were the most discriminative between the two groups, emphasizing the importance of performing the functional test. 


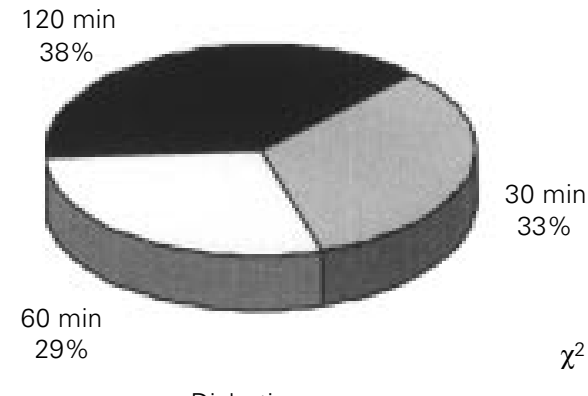

Diabetic group

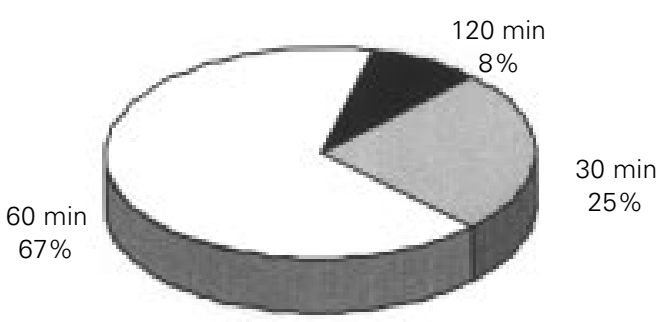

$\chi^{2}=8.06^{*}$

Figure 4 - Comparison between type 1 diabetic $(\mathrm{N}=26)$ and nondiabetic ( $N=24$ ) groups in terms of time for maximum C-peptide response to a test meal. ${ }^{*} \mathrm{P}<0.03$ compared to the diabetic group (chi-square test).

The percent increase was not an adequate parameter to evaluate the $B$ cell response in our group of type 1 diabetics because the patients could have more than a $100 \%$ increase in their C-peptide levels and still present a low value.

Although a good correlation between BV and PV was found, in agreement with other studies $(9,10)$, basal values were unable to discriminate patients with and without the capacity to respond to the stimulus. The studies $(2,22)$ which tried to establish a threshold basal level described different values which were not $100 \%$ discriminative.

In the present study, most non-diabetics showed maximum $\mathrm{C}$-peptide responses at 60 min. In diabetic patients, there was no definite pattern in the time of maximum responses, but we found a large number of late responses (at $120 \mathrm{~min}$ ), as described in the literature $(3,23)$.

The present results show heterogeneity in levels and responses of C-peptide in a group of type 1 diabetic patients with up to two years of disease. Future studies will be needed to determine if these observations are associated with a heterogeneous pattern of evolution of the disease after diagnosis.

In the present study the functional test proved to be an important tool to evaluate residual insulin secretion because $\mathrm{BV}$ was unable to discriminate the capacity of responding to stimulation. The variables after the stimulus (PV, AI, IA, and TA) were the most discriminative between the two groups. The analysis of more than one sample after the stimulus was a relevant aspect because the time of maximum response was quite variable in the diabetic group.

\section{References}

1. Assan R, Feutren G, Sirmai J, Lebsiene C, Boitard C, Vexian P, Du Rostu H, Rodier M, Figoni M, Vague $P$, Hors J \& Bach J-F (1990). Plasma C-peptide levels and clinical remissions in recent onset type I diabetic patients treated with cyclosporin A and insulin. Diabetes, 39: 768-774.

2. Clarson C, Daneman D, Drash AL, Becker DJ \& Ehrlich RM (1987). Residual B-cell function in children with IDDM: reproducibility of testing and factors influencing insulin secretory reserve. Diabetes Care, 10: 33-38.

3. Faber OK \& Binder C (1977). C-peptide response to glucagon: a test for the residual B-cell function in diabetes mellitus. Diabetes, 26: 605-610.
4. Schiffrin A, Suissa S, Witzner G, Poussier $P$ \& Lalla D (1992). Factor predicting course of $ß$-cell function in IDDM. Diabetes Care, 15: 997-1001.

5. Snorgaard O, Lassen LH \& Binder C (1992). Homogeneity in pattern of decline of B-cell function in IDDM - prospective study of 204 consecutive cases followed for 74 years. Diabetes Care, 15: 10091013.

6. Dahlquist G, Blom L, Bolme P, Hagenfeldt $L$, Lindgren F, Persson B, Thalme B, Theorell M \& Westin S (1982). Metabolic control in 131 juvenile-onset diabetic patients as measured by $\mathrm{Hb} \mathrm{A} 1 \mathrm{C}$ : relation to age, duration, C-peptide, insulin dose, and one or two insulin injections. Diabetes Care, 5: 399-403.
7. Ludvigsson J \& Heding LG (1976). C-peptide in children with juvenile diabetes. Diabetologia, 12: 627-630.

8. Mirel RD, Ginsberg-Feltner F, Horwitz DL \& Rayfield EJ (1980). C-peptide reserve in insulin-dependent diabetes: comparative responses to glucose, glucagon and tolbutamide. Diabetologia, 19: 183-188.

9. Garcia-Webb P (1982). Correlation between fasting serum C-peptide and $ß$-cell insulin secretory capacity in diabetes mellitus. Diabetologia, 22: 296.

10. Gjessing $\mathrm{HJ}$, Matzen LE, Fraland A \& Faber OK (1987). Correlation between fasting plasma C-peptide, glucagon-stimulated plasma C-peptide, and urinary Cpeptide in insulin-treated diabetics. Diabetes Care, 10: 487-490. 
11. The DCCT Research Group (1987). Effects of age, duration and treatment of insulin dependent diabetes mellitus on residual B-cell function: observations during eligibility testing for the diabetes control and complications trial (DCCT). Journal of Clinical Endocrinology and Metabolism, 65: 30-36.

12. Wallesteen $M$, Dahlquist G, Persson B, Landin-Olsson M, Lernmark A, Sundkuist $G$ \& Thalme B (1988). Factors influencing the magnitude duration and rate of fall of B-cell function in type I (insulin-dependent) diabetic children followed for two years from their clinical diagnosis. Diabetologia, 31: 664-669.

13. Sochett E, Daneman D, Clarson C \& Ehrlich RM (1987). Factors affecting and patterns of residual insulin secretion during the first year of type I (insulin dependent) diabetes mellitus in children. Diabetologia, 30: 453-459.

14. Rjasanowski I, Michaelis D, Keilacker $H_{\text {, }}$ Besch W, Richter KV \& Heinke P (1987). 5-year follow-up study of C-peptide secretion in newly diagnosed type I diabetics: relations to HLA-phenotype, insulin requirement and metabolic control. Experimental and Clinical Endocrinology, 89: 216-224
15. Fukuda $\mathrm{M}$, Tanaka $\mathrm{A}$, Tahara $\mathrm{Y}$, Ikegami $\mathrm{H}$ Yamamoto Y, Kumahara Y \& Shima K (1988) Correlation between minimal secretory capacity of pancreatic ß-cells and stability of diabetic control. Diabetes, 37: 81-88.

16. Sberna $P$, Valentini $V$, Cimino A, Sabathi MC, Rotondi A, Crisetig M \& Spandrio S (1986) Residual $ß$-cell function in insulin-dependent (type I) diabetics with and without retinopathy. Acta Diabetologica Latina, 23: 339344

17. Hsieh SD, Kanazawa $Y$ \& Akanuma $Y$ (1985). Serum free C-peptide response to oral glucose loading as a parameter for the monitoring of pancreatic B-cell function in diabetic patients. Diabetes Research and Clinical Practice, 1: 109-114.

18. Le Floch JP, Escuyer P, Boudin E, Baudon D \& Perlemuter L (1990). Blood glucose area under the curve. Methodological aspects. Diabetes Care, 13: 172-175.

19. National Diabetes Data Group (1979). Classification and diagnosis of diabetes mellitus and other categories of glucose intolerance. Diabetes, 28: 1039-1057.
20. Siegel S (1975). Estatística não Paramétrica. 1st edn. McGraw-Hill, São Paulo.

21. Keilacker $H$, Kohnert K-D \& Ziegler $M$ (1990). Influence of polyethylene glycol (PEG) extraction on the C-peptide determination in sera from insulin-dependent diabetic patients with circulating insulin antibodies. Experimental and Clinical Endocrinology, 95: 119-122.

22. Hendriksen C, Faber OK, Dreger J \& Binder C (1977). Prevalence of residual $ß$ cell function in insulin-treated diabetics evaluated by plasma C-peptide response to intravenous glucagon. Diabetologia, 13: 615-619.

23. Faber OK \& Binder C (1977). B-cell function and blood glucose control in insulin dependent diabetics within the first month of insulin treatment. Diabetologia, 13: 263-268. 